\title{
Correction to: Perfusion MRI in CNS disease: current concepts
}

\section{Essig ${ }^{1} \cdot$ F. Giesel $^{1}$ - M. Le-Huu ${ }^{1}$ - B. Stieltjes ${ }^{1} \cdot$ H. von Tengg-Kobligk ${ }^{1} \cdot$ M.-A. Weber ${ }^{1}$}

Published online: 25 March 2020

(C) Springer-Verlag GmbH Germany, part of Springer Nature 2020

\section{Correction to: Neuroradiology (2004) 46: S201-S207} https://doi.org/10.1007/s00234-004-1331-y

The above article was published with one author name being incorrect. The published paper states " $\mathrm{H}$. von Tengg", whereas it should be "H. von Tengg-Kobligk". The author name has been corrected above. 